\title{
Potential of Pandanus odoratissimus as a CNS depressant in Swiss albino mice
}

\author{
Sama Raju, ${ }^{1, *}$ Narra Venkata Subbaiah ${ }^{1}$, Kandukuri Sreeramulu Reddy ${ }^{1}$, \\ Amit Das', Krishnan Bala Murugan²
}

${ }^{I}$ Clinical Research Department, Shantha Biotechnics Limited, Andhra Pradesh, India,

${ }^{2}$ Department of Pharmacy, Annamalai University, Chidambaram, Tamilnadu, India

\begin{abstract}
In this study, several neuropharmacological effects of methanolic leaf extract of Pandanus odoratissimus (PO) (family; Pandanaceae) were studied in albino mice using various experimental models. The effect of $\mathrm{PO}$ on the CNS was studied by using different neuropharmacological paradigms including spontaneous motor activity, rota-rod performance and potentiation of Pentobarbital sodium sleeping time in albino mice. Preliminary phytochemical evaluation and acute toxicity studies were also carried out where $\mathrm{LD}_{50}$ $>2000 \mathrm{mg} / \mathrm{kg}$ was considered non-toxic through acute exposure in rats by the oral route. The methanolic leaf extract $(50,100$ and $200 \mathrm{mg} / \mathrm{kg}$ i. p.) produced a reduction in spontaneous motor activity, motor coordination and prolonged Pentobarbital sodium sleeping time. Preliminary qualitative chemical studies indicated the presence of steroids, saponins, terpinoids, glycosides, tannins, flavonoids and phenolics in the extract. These observations suggest that the leaf of Pandanus odoratissimus contains some active principles which possess potential CNS-depressant action
\end{abstract}

Uniterms: Pandanus odoratissimus/pharmacognosy. CNS-depressant action/experimental study. Spontaneous motor activity. Rota-rod performance. Sodium pentobarbital/potentiation of sleeping time.

Estudaram-se alguns efeitos neurofarmacológicos do extrato metanólico de Pandanus odoratissimus (PO) (família Pandanaceae) em camundongos albinos, usando vários modelos experimentais. O efeito do PO no SNC foi estudado por meio de diferentes paradigmas neurofarmacológicos, como atividade motora espontânea, desempenho na haste rotatória e a potenciação do tempo de sono em camundongos albinos pelo pentobarbital sódico. A avaliação fitoquímica preliminar e os estudos de toxicidade aguda foram realizados e a $\mathrm{DL}_{50}>2000 \mathrm{mg} / \mathrm{kg}$ é considerada não tóxica, por meio da exposição aguda, por via oral, em ratos. O extrato metanólico de folha $(50,100$ e $200 \mathrm{mg} / \mathrm{kg}$ i. p.) produziu redução da atividade motora espontânea, da coordenação motora e tempo prolongado de sono pelo pentobarbital sódico. Estudos químicos qualitativos preliminares indicaram a presença de esteróide, saponinas, terpenóides, glicosídios, taninos, flavonóides e fenólicos no extrato. As observações sugerem que a folha de Pandanus odoratissimus contém alguns princípios ativos com atividade potencial como depressores do SNC.

Unitermos: Pandanus odoratissimus/farmacognosia. Ação depressor do SNC/estudo experimental. Atividade motora espontânea. Desempenho na haste rotatória. Pentobarbital sódico/potenciação no tempo de sono.

\section{INTRODUCTION}

Pandanus odoratissimus L. syn. P. fascicularis Lam. (Pandanaceae) is commonly known as 'kewda' or 'keora' in Hindi, Marathi and Gujrati; 'kiya' in Oriya and Bengali and 'mogali' in Telugu (The Wealth of India, 1966). Pandanus odoratissimus is said to be a restorative, indolent,

*Correspondence: Sama. Raju. Clinical Research Department, Shantha Biotechnics Limited, Basheer Bagh, Hyderabad, Andhra Pradesh, India, 500004. E-mail: rajenderreddysama@gmail.com promoting a feeling of well-being and acting as a counter to tropical climates. It may be chewed as a breath sweetener or used as a preservative in foods. It is also believed to have health-related properties, including antiviral, anti-allergy, antiplatelet, anti-inflammatory, antioxidant and anticancer action. Ayurvedic science has found the medicinal action of essential oil yielded by the screw pine's highly scented flowers to be useful in headaches, earaches and as a liniment for rheumatic pains. The distilled water from flowers is used for inducing perspiration. It is also prescribed as a stimulant 
and an antispasmodic agent. The flowers are powdered and included in medicines, which are either sniffed like snuff or smoked for asthma and other bronchial infections (Keerthikar, Basu, 2000). The leaves are thought to be useful in leprosy, smallpox, scabies and diseases of the heart and brain. Medicinal oil is also prepared from the roots of Pandanus odoratissimus (The Wealth of India, 1966). The methanolic extract of the leaf is said to have moderate antioxidant activity because of its high phenolic content. Other constituents present in the methanolic leaf extract are steroids, saponins, terpinoids, glycosides, tannins and flavonoids (Londonkar et al., 2009). To the best of our knowledge, no studies on the Pandanus odoratissimus in the central nervous system have been reported. Pilot studies have indicated that leaf extract of Pandanus odoratissimus has a role in the CNS. Based on this evidence, we investigated the activity of the methanolic extract of Pandanus odoratissimus on motor coordination, spontaneous motor activity and pentobarbital induced sleeping time in albino mice.

\section{MATERIALS AND METHODS}

\section{Preparation of plant extract}

The leaves of the herb Pandanus odoratissimus were collected in September from villages surrounding Chidambaram, Tamilnadu, India. The fresh leaves of Pandanus odoratissimus were then washed with running water. The leaves were shade dried at room temperature and $1 \mathrm{~kg}$ of the dried leaf was ground into coarse powder. The powder was passed through a no. 60 mesh sieve. The ground power was extracted using methanol in a soxhlet apparatus (Harborne, 1973). The extract was then evaporated under reduced pressure to give a dark green viscous mass. The methanolic extract (a dark green viscous mass) was dried and stored in a desiccator prior to use and gave a mean yield of $15.5 \% \mathrm{w} / \mathrm{w}$. The dried extract was dissolved in a saline solution $(5 \mathrm{mg} / \mathrm{mL})$ prior to use (Perez et al., 1998).

\section{Animals}

Young adult Swiss albino mice weighing 20-25g of either sex were obtained from the central animal house of Annamalai University, Chidambaram, Tamilnadu, India. The animals were maintained in colony cages at $25 \pm 2{ }^{\circ} \mathrm{C}$, a relative humidity of 50-55\%, under a 12:12 h light and dark cycle. The animals were fed with standard animal feed (Hindustan Lever Ltd. Bangalore, India) and water; animals were acclimatized to the laboratory conditions for 5 days prior to experimentation. All experiments were car- ried out according to the guidelines for care and use of experimental animals, and were approved by the Committee for the Purpose of Control and Supervision of Experiments on Animals (CPCSEA). Study proposal number 406 was approved by the Institutional Animal Ethical Committee, Rajah Muthaiah Medical College, Annamalai University, Chidambaram, Tamilnadu, India.

\section{Drugs and chemicals}

Some of the drugs and chemicals used for carrying out the studies included: Diazepam (Calmpose ${ }^{\circ}$; Ranbaxy, India), sodium pentobarbital (Loba Chemie Indo Austranal Co. Mumbai, India) and methanol (SD fine chemicals Limited, Mumbai, India).

\section{Acute toxicity study}

\section{Experimental animals ; and administration}

For determination of the dose of $\mathrm{LD}_{50}$, seven-weekold male and female albino mice, weighing between 20-25 $\mathrm{g}$ were used. Animals were randomly assigned to control or treatment groups (5 mice/sex group). Animals were deprived of food but given water 16-18 hours prior to dosing on day 0 . The extract at a dose of $2000 \mathrm{mg} / \mathrm{kg}$ was then given orally to test group of mice, while the control group received water at the same volume by gavage using a ball-tipped stainless steel feeding needle.

\section{Observation of toxicity signs}

Body weight, signs of toxicity (general behavior, respiratory pattern, cardiovascular signs, motor activities, reflexes, and change in skin and fur) and mortality were observed after administration at the first, second, fourth and sixth hour on the first day, and once daily for the proceeding 14 days (OECD guidelines, 2001).

\section{Spontaneous motor activity (SMA)}

Mice were placed into groups of six animals each and treated with saline or the PO extract $(50,100$ and $200 \mathrm{mg} / \mathrm{kg}$ i.p.) or received diazepam $1 \mathrm{mg} / \mathrm{kg}$ i.p. Spontaneous motor activity was monitored by using an Actophotometer (Techno LE3806, India). After 30 min of treatment, for monitoring of the SMA each mouse was placed in a Plexiglass cage and isolated in the recording room. The experiments were repeated at an interval of $30 \mathrm{~min}$ for a total of $120 \mathrm{~min}$. The sensing platform reacts to the lateral component of the animals' movements and recordings of displacement were taken over 10-min periods. Results of the treated groups were compared with those of the control group for each time interval (Amos et al., 2001). 


\section{Motor coordination by rota-rod test}

Dunham and Miya suggested that skeletal muscle relaxation induced by a test compound could be evaluated by testing the ability of mice or rats to remain on a rotating rod. (Dunham et al., 1957). For this purpose Rota-rod (Techno, India) biological research apparatus was used for the test. The instrument (a horizontal rotation device) was set at a rate of 16 revolutions per minute. Mice were placed on the rod and those that were able to remain on the rod longer than 3 min were selected for the study. Group 1 was treated with saline; while group 2, 3 and 4 received the PO extract at a dose of 50,100 and $200 \mathrm{mg} / \mathrm{kg}$ i.p. respectively. Group 5 received diazepam $1 \mathrm{mg} / \mathrm{kg}$ i.p. Mice unable to remain on the rod for at least three min were considered as a positive test and the time of their fall was recorded. (Perez et al., 1998).

\section{Sodium pentobarbital induced sleeping time}

Mice of either sex were randomly allocated to the different control and test groups (6 animals per group). Animals were treated as follows; Group 1 received normal saline while groups 2, 3 and 4 received the extract (dose 50,100 and $200 \mathrm{mg} / \mathrm{kg}$ i.p). Group 5 received only diazepam $1 \mathrm{mg} / \mathrm{kg}$ i.p. Animals were administered with sodium pentobarbital ( $40 \mathrm{mg} / \mathrm{kg}$ i.p.) $30 \mathrm{~min}$ later and the index of hypnotic effect was recorded. The effects were recorded as follows: time elapsed between the administrations of pentobarbital until loss of righting reflex was recorded as of the onset of sleep, while the time from the loss to recovery was considered as the duration of sleep (Ming-Chin Lu et al., 1998).

\section{Statistical analysis}

The results for the sodium pentobarbital induced sleeping time; Spontaneous motor activity and the motor coordination test were reported as mean \pm SEM. Differences in means were estimated by using the ANOVA test. The mean values of the results from the control group were compared to the mean values of groups treated with extract using the Dunnett post hoc test. The results were considered significant at $P<0.05$.

\section{RESULTS AND DISCUSSION}

\section{Acute toxicity and general behavioral studies}

Both female and male mice administered with the extract at a dose of $2000 \mathrm{mg} / \mathrm{kg}$ showed no toxicity during the experimentation period. In both sexes of mice, body weight gain of treatment rats was not changed significantly relative to that of control. While conducting the toxicity studies, animals were observed continuously for any general behavioral changes. A significant reduction in spontaneous locomotor motility, drowsiness and remarkably quiet behavior were observed. Thus, the extract of Pandanus odoratissimus with an $\mathrm{LD}_{50}>2000 \mathrm{mg} / \mathrm{kg}$ is considered non-toxic through acute exposure in mice.

\section{Spontaneous motor activity}

PO produced a significant decrease in spontaneous motor activity among mice at the doses of 50,100 and $200 \mathrm{mg} / \mathrm{kg}$ i.p. This effect was dose dependent and observed within $30 \mathrm{~min}$ of drug administration, persisting for $120 \mathrm{~min}$. The statistical comparisons made between the treated groups and normal saline control group showed a significant $(p<0.01)$ reduction for the extract containing $50 \mathrm{mg} / \mathrm{kg}$ i.p. at $120 \mathrm{~min}$, for the extracts of 100 and $200 \mathrm{mg} / \mathrm{kg}$ i.p. at $90 \mathrm{~min}$, and for diazepam ( $1 \mathrm{mg} / \mathrm{kg}$ i.p. $)$ at 30, 60,90 and $120 \mathrm{~min}$ intervals (Table I).

\section{Motor coordination}

PO produced a marked reduction in motor coordination in mice where the animals were unable to remain on

TABLE I - Effect of PO extract on spontaneous motor activity

\begin{tabular}{lcccccc}
\hline Treatment & Drug mg/kg & \multicolumn{5}{c}{ Experimental mean time (min) \pm SEM } \\
\cline { 2 - 6 } & & $0 \mathrm{~min}$ & $30 \mathrm{~min}$ & $60 \mathrm{~min}$ & $90 \mathrm{~min}$ & $120 \mathrm{~min}$ \\
\hline Control & Saline & $410.67 \pm 2.62$ & $381.33 \pm 1.64^{* *}$ & $170.33 \pm 1.30$ & $197.50 \pm 1.89$ & $244.17 \pm 2.75$ \\
Extract & 50 & $411.00 \pm 1.67$ & $95.50 \pm 2.39^{* *}$ & $79.50 \pm 2.01^{* *}$ & $81.33 \pm 1.01^{* *}$ & $72.83 \pm 1.35^{* *}$ \\
& 100 & $427.00 \pm 1.98$ & $67.16 \pm 1.16^{* *}$ & $47.16 \pm 2.13^{* *}$ & $32.66 \pm 1.33^{* *}$ & $57.50 \pm 1.11^{* *}$ \\
& 200 & $439.17 \pm 1.77$ & $39.167 \pm 0.94^{* *}$ & $22.33 \pm 1.28^{* *}$ & $18.50 \pm 0.76^{* *}$ & $18.33 \pm 0.66^{* *}$ \\
Diazepam & 1 & $423.17 \pm 3.15$ & $32.00 \pm 1.31^{* *}$ & $20.66 \pm 2.31^{* *}$ & $17.00 \pm 2.32^{* *}$ & $9.167 \pm 1.83^{* *}$ \\
\hline
\end{tabular}

SEM = Standard error of mean; $(\mathrm{n}=6)$ *significantly different at $\mathrm{P}<0.05$.; ** significantly different at $\mathrm{P}<0.01$. using analysis of Variance (ANOVA) 
TABLE II - Effect of PO extract on motor coordination in mice

\begin{tabular}{lcccccc}
\hline Treatment & Drug mg/kg & \multicolumn{5}{c}{ Experimental mean time (min) \pm SEM } \\
\cline { 3 - 6 } & & 0 min & $30 \min$ & $60 \min$ & 90 min & 120 min \\
\hline Control & Saline & $194.50 \pm 1.60$ & $197.67 \pm 2.02$ & $196.50 \pm 2.07$ & $197.17 \pm 1.86$ & $198.50 \pm 2.11$ \\
Extract & 50 & $196.83 \pm 1.35$ & $78.66 \pm 1.25^{* *}$ & $81.00 \pm 0.73^{* *}$ & $125.00 \pm 1.23^{* *}$ & $149.33 \pm 0.88^{* *}$ \\
& 100 & $196.50 \pm 1.47$ & $66.33 \pm 0.88^{* *}$ & $70.16 \pm 1.24^{* *}$ & $119.33 \pm 3.98^{* *}$ & $132.67 \pm 1.82^{* *}$ \\
& 200 & $196.67 \pm 1.43$ & $48.66 \pm 1.20^{* *}$ & $64.16 \pm 1.24^{* *}$ & $119.17 \pm 5.45^{* *}$ & $116.83 \pm 3.15^{* *}$ \\
Diazepam & 1 & $198.50 \pm 1.54$ & $36.33 \pm 1.49^{* *}$ & $47.66 \pm 1.54^{* *}$ & $97.50 \pm 1.33^{* *}$ & $92.50 \pm 2.77^{* *}$ \\
\hline
\end{tabular}

$\mathrm{SEM}=$ Standard error of mean; $(\mathrm{n}=6)$ * significantly different at $\mathrm{P}<0.05$.; **significantly different at $\mathrm{P}<0.01$. using analysis of Variance (ANOVA)

the rotating rod. This effect was dose-dependent and was observed within 30 min of drug administration, persisting for $120 \mathrm{~min}$. The statistical comparisons made between the treated groups and normal saline control group showed a significant $(\mathrm{p}<0.01)$ reduction for the extracts of 50,100 and $200 \mathrm{mg} / \mathrm{kg}$ i.p. at $30 \mathrm{~min}$, and for diazepam $(1 \mathrm{mg} / \mathrm{kg}$ i.p. $)$ at 30 and $60 \mathrm{~min}$ intervals (Table II).

\section{Sodium pentobarbital induced sleeping time}

Prior administration of PO caused a significant reduction in the onset of sodium pentobarbital (40 mg/kg i.p.)-induced sleep at 50, 100 and $200 \mathrm{mg} / \mathrm{kg}$ doses. This effect was dose-dependent and results reached significance $(P<0.01$ and $P<0.05)$ compared with the Pentobarbital sodium treated control group. Various sleep times of mice treated with pentobarbital with or without extract are shown in Table III.

In the present study, several neuropharmacological effects of PO in mice were reported, employing different

TABLE III - Effect of PO extract on sodium pentobarbital-induced sleeping time in mice

\begin{tabular}{lccc}
\hline Treatment & Drug mg/kg & $\begin{array}{c}\text { Onset of } \\
\text { sleep(min) } \\
\text { SEM }\end{array}$ & $\begin{array}{c}\text { Duration of } \\
\text { sleep }(\mathrm{min}) \pm \\
\text { SEM }\end{array}$ \\
\hline $\begin{array}{l}\text { Pentobarbital } \\
\text { sodium }\end{array}$ & 40 & $3.57 \pm 0.36$ & $41.12 \pm 0.33$ \\
Extract & 50 & $2.60 \pm 0.22^{*}$ & $68.66 \pm 0.47^{* *}$ \\
& 100 & $2.26 \pm 0.16^{* *}$ & $71.66 \pm 0.49^{* *}$ \\
& 200 & $2.16 \pm 0.12^{* *}$ & $88.83 \pm 0.55^{* *}$ \\
Diazepam & 1 & $2.00 \pm 0.25^{* *}$ & $94.33 \pm 0.66^{* *}$ \\
\hline
\end{tabular}

SEM $=$ Standard error of mean; $(n=6)$ *significantly different at $\mathrm{P}<0.05$.; ${ }^{* *}$ significantly different at $\mathrm{P}<0.01$. using analysis of Variance (ANOVA) validated animal models. These actions were compared to the effects produced by Diazepam, a standard benzodiazepine commonly used as an anxiolytic in clinics. It is generally accepted that the sedative/CNS depressant effect of drugs can be evaluated by measurement of spontaneous motor activity and sodium pentobarbital-induced sleeping time in laboratory animal models (Ming-chin et al., 1998). These results corroborate those of (Fujimori et al., 1995), who proposed that the enhancement of barbital hypnosis is a good index of CNS depressant activity. Our data showed that i.p treatment with PO extract produced alterations in general behavioral pattern, a significant reduction in spontaneous motor activity, motor coordination and potentiation of pentobarbital-induced sleeping time in a dose dependent fashion. Spontaneous motor activity is a measure of the level of excitability of the CNS (Mansur et al., 1971) which correlates well with drug effects in humans. Agents that suppress this behavior usually do so through central inhibition (Adzu et al., 2002). The significant $(\mathrm{p}<0.01)$ reduction in spontaneous motor activity caused by the PO extract therefore suggests a reduction in the excitability of the central nervous system which in turn could be suggestive of sedative activity (Ozturk et al., 1996). The test most widely employed to evaluate the putative hypnosedative properties of compounds with unknown central nervous system effects is barbiturate-induced sleep (Duarte et al., 2007). Pentobarbital sodium, when given at an appropriate dose, induces sedation or hypnosis in animals by potentiating GABA-mediated postsynaptic inhibition through allosteric modification of GABA receptors (Collier et al., 1968). Substances that have CNS depressant activity either decrease the time for onset of sleep or prolong the duration of sleep or both. PO decreased the time for onset of sleep and also prolonged Pentobarbital sodium-induced sleeping time in a dose dependent fashion. Prolongation of sodium pentobarbital-induced hypnosis is suggestive of central depressant activity of a compound 
(Perez et al., 1998). The test for motor coordination (rota rod performance) was adopted to evaluate the effect of the extract on physical performance, endurance and possible neuromuscular inhibition. The dopaminergic system has traditionally been regarded as crucial to the control of motor activity (Petry et al., 1993). PO has a significant effect on in vivo muscle relaxant activity as indicated by positive results obtained in the grip strength test. Therefore, this suggests that the extract has centrally-mediated actions. Phytochemical analysis of the extract showed the presence of alkaloids, flavonoids, saponins, steroids, terpinoids, tannins and glycosides. The saponins and flavonoids have been reported to be responsible for a sedative effect and likewise for inhibition of spontaneous motor activity in mice (Musa et al., 2006). These results are supported by several researchers (Won et al., 1980; Dubois et al., 1986). Reported pharmacological activities of PO could be attributed to the presence of saponins and flavonoids. Further studies focusing on the isolation and characterization of these secondary metabolites are needed.

\section{CONCLUSION}

Based on the findings of the present study, it can be concluded that the methanolic leaf extract of Pandanus odoratissimus possesses significant CNS depressant activity. The depressant activity may be attributed to various mechanisms such as decreased serotonergic and dopaminergic transmission. The present study is based upon the behavioral models with crude extract and without any associated neurochemical estimations. Therefore, to determine the exact mechanism of action of Pandanus odoratissimus, studies with purified/bioactive compounds are warranted, with specific binding studies and estimations of the neurotransmitter levels in the brain in an effort to understand the exact mechanism of action and extend these results further.

\section{REFERENCES}

ADZU, B.; AMOS, S.; DZARMA, S.; WAMBEBE, C.; GAMANIEL, K. Effect of Zizypus spinachristi wild aqueous extract on the central nervous system in mice. $J$. Ethnopharmacol., v.79, p.13-16, 2002.

AMOS, B.; ADZU, L.; BINDA, C.; W.; GAMANIEL, K. Behavioral effects of the aqueous extract of Guiera senegalensisi in mice and rats. Phytomedicine, v.8, p.356$361,2001$.
ANONYMOUS. The Wealth of India: raw materials. New Delhi: Publications and Information Directorate, CSIR, 1966. v.7, p.218-220.

COLLIER, H.O.; DINNEEN, L.C.; JOHNSON, C.A; SCHNEIDER, C. The abdominal constriction response and its suppression by analgesic drugs in the mouse. $B r . J$. Pharmacol., v.32, p.295-310, 1968.

DUARTE, F.S.; DUZZIONI, M.; MENDES, B.G.; PIZZOLATTI, M.G.; DE LIMA. T.C.M. Participation of dihydrostyryl-2-pyrones and styryl-2-pyrones in the central effects of Polygala sabulosa (Polygalaceae), a folk medicine topical anesthetic. Pharmacol. Biochem. Behav., v.86, p.150-161, 2007.

DUBOIS, M.A.; ILYAS, M.; WAGNAR, H. Cussonosides A \& B, two triterpenes-saponins from Cussonia barteri. Planta Med., v.56, p.80-83, 1986.

DUNHAM, N.W.; MIYA, T.S. A note on a simple apparatus for detecting neurological deficit in rats and mice. $J . A m$. Pharm. Assoc., v.46, p.208-209, 1957.

FUJIMORI, H.; COBB, D. Potentiation of barbital hypnosis as an evaluation method for central nervous system depressant. Psychopharmacology, v.7, p.374-377, 1995.

HARBORNE, J.B. Phytochemical methods: a guide to modern techniques of plant analysis. London: Chapman and Hall Publishers, 1973. p.4-7.

KIRTIKAR, K. R.; BASU, B. D. Text book of Indian medicinal plants. Allahabad: International Book Distributors, 2000. v.II, p.3566-3569.

LONDONKAR, R.; KAMBLE, A. Evaluation of free radical scavenging activity of Pandanus odoratissimus. Int. J. Pharmacol., v.5, p.377-380, 2009.

MANSUR, J.; MARTZ, R.M.W.; CARLINI, E.A. Effects of acute and chronic administration of cannabis satis and (-) 9-trans tetrahydrocannabinol on the behaviour of rats in open field arena. Psychopharmacology., v.19, p.338-397, 1971.

MING-CHIN, L.U. Studies on the sedative effect of Cistanche deserticola. J. Ethnopharmacol., v.59, p.161-165, 1998. 
MUSA, A.M.; YARO, A.H.; DANJUMA, N.M. Preliminary phytochemical screening and central nervous system depressant activity of the stem bark of Picus thoningii Blums. Biol. Environ. Sci. Trop. J., v.3, p.1-6, 2006.

ORGANIZATION FOR ECONOMIC COOPERATION AND DEVELOPMENT (OECD).Guidelines for the Testing of Chemicals No. 420: Acute Oral Toxicity - Fixed Dose Procedure. Paris, 2001. p.14.

OZTURK, Y.; AYDINI, S.; BEIS, R.; BASER, K.H.C.; BERBEROGLU, H. Effect of Hypericum Pericum L. and Hypericum Calycinum L. extracts on the central nervous system in mice. Phytomedicine, v.3, p.139-146, 1996.
PEREZ, R.M.; PEREZ, J.A.; GARCIA, L.M.; SOSSA, H. Neuropharmacological activity of Solanum nigrum fruit. J. Ethnopharmacol., v.62, p.43-48. 1998.

PETRY, N.; FUMIDGE, L.; TONG, Z.Y.; MARTIN, C.;CLARK, D. Time sampling observation procedure for studying interaction between d-amphetamine and selective DA receptor in the rats. Pharmacol. Biochem. Behav., v.446, p.167-80, 1993.

WON, S.W.; KUK, H.S.; SAM, S.K. Chemistry and pharmacology of flavones-C glycosides from zizipus seeds. Korean J. Pharm., v.11, p.141-148, 1980.

Received for publication on $3^{\text {rd }}$ February 2010 Accepted for publication on $18^{\text {th }}$ April 2011 